Article

\title{
Antibacterial, Antioxidant, and Antiproliferative Activities of Corymbia citriodora and the Essential Oils of Eight Eucalyptus Species
}

\author{
Maria Graça Miguel ${ }^{1}$ * (D) , Custódia Gago ${ }^{2}$, Maria Dulce Antunes ${ }^{3}$, Soraia Lagoas ${ }^{4}$, \\ Maria Leonor Faleiro ${ }^{4}$, Cristina Megías ${ }^{5}$, Isabel Cortés-Giraldo ${ }^{5}$, Javier Vioque ${ }^{5}$ (D) and \\ Ana Cristina Figueiredo 6 (iD) \\ 1 Departamento de Química e Farmácia, Faculdade de Ciências e Tecnologia, Universidade do Algarve, \\ MeditBio, Campus de Gambelas, 8005-139 Faro, Portugal \\ 2 MeditBio, Faculdade de Ciências e Tecnologia, Universidade do Algarve, Campus de Gambelas, \\ 8005-139 Faro, Portugal; cgago@ualg.pt \\ 3 CEOT/MeditBio Faculdade de Ciências e Tecnologia, Universidade do Algarve, Campus de Gambelas, \\ 8005-139 Faro, Potugal; mantunes@ualg.pt \\ 4 Centre for Biomedical Research (CBMR), Faculdade de Ciências e Tecnologia, Universidade do Algarve, \\ Campus de Gambelas, 8005-139 Faro, Potugal; soraia_s_s@hotmail.com (S.L.); mfaleiro@ualg.pt (M.L.F.) \\ 5 Instituto de la Grasa (C.S.I.C.), Universidad Pablo de Olavide, Edificio 46, Carretera de Utrera, km 1, \\ 41013 Sevilla, Spain; cmegias@cica.es (C.M.); icortes@ig.csic.es (I.C.-G.); jvioque@cica.es (J.V.) \\ 6 Centro de Estudos do Ambiente e do Mar (CESAM Lisboa), Faculdade de Ciências da Universidade de \\ Lisboa, Centro de Biotecnologia Vegetal (CBV), DBV, C2, Campo Grande, 1749-016 Lisboa, Portugal; \\ acsf@fc.ul.pt \\ * Correspondence: mgmiguel@ualg.pt; Tel.: +351-289-800-100
}

Received: 16 May 2018; Accepted: 13 June 2018; Published: 21 June 2018

Abstract: Background: Essential oils (EOs) have shown antimicrobial, antioxidant, and antiproliferative activity, which may, alone or in combination with other substances, potentially be used for the development of new drugs. However, their chemical variability, depending on the species, varieties, or geographical origin (among other factors) determines different bioactivities that need to be evaluated. Methods: The antioxidant activity of Corymbia citriodora and eight Eucalyptus species EOs was determined using two different methods: the scavenging ability of 2,2'-azino-bis(3-ethylbenzothiazoline-6-sulphonic acid) $\left(\mathrm{ABTS}^{+\bullet}\right)$ and peroxyl free radicals or oxygen radical absorbance capacity (ORAC). Antibacterial activity was evaluated using the microorganisms Streptococcus pneumoniae (strains D39 and TIGR4), and Haemophilus influenza (strain DSM 9999). The essential oils' minimum inhibitory concentration (MIC) and minimum bactericidal concentration (MBC) was assessed using a microdilution method. The antiproliferative activity was determined using the THP-1 cell line (human acute monocytic leukaemia) with methylthiazolyldiphenyl-tetrazolium bromide assay (MTT). Results: Corymbia citriodora and Eucalyptus viminalis EOs showed the highest ABTS and peroxyl free radical scavenging capacity. Eucalyptus globulus EO showed a high potential to treat Streptococcus pneumoniae infections. Haemophilus influenzae was the respiratory pathogen that showed the highest resistance to all EOs, including tea tree EO. After $96 \mathrm{~h}$ of incubation, at $25 \mu \mathrm{g} / \mathrm{mL}$, Eucalyptus radiata and Eucalyptus viminalis EOs showed highest cytotoxic activity against the THP-1 cell line. Conclusions: Despite their specific bioactivities, no single EO showed simultaneously good antioxidant, antimicrobial, and antiproliferative activity.

Keywords: Corymbia citriodora; Eucalyptus dives; Eucalyptus globulus; Eucalyptus delegatensis subsp. tasmaniensis; Eucalyptus pauciflora; Eucalyptus radiata; Eucalyptus smithii; Eucalyptus urophylla; Eucalyptus viminalis 


\section{Introduction}

Streptococcus pneumoniae, Staphylococcus aureus, and Haemophilus influenzae may asymptomatically colonize the upper respiratory tract and are the etiologic agents of acute otitis media, sinusitis, and pneumonia. S. pneumoniae is also responsible for bacterial meningitis [1,2]. Nowadays, the treatment of these diseases is threatened by the development of antibiotic resistance worldwide [3]. Essential oils (EOs) and their isolated compounds have been shown to possess antimicrobial activity against several pathogens [4]. The complex mixtures that generally constitute EOs can be advantageous because pathogens have difficulty in displaying resistance mechanisms to the multiple constituents of essential oils $[5,6]$.

Reactive oxygen species (ROS) have a physiological role in normal cell function, but when their production exceeds their elimination, an excess of ROS in the body occurs and consequently, diseases also arise because ROS can damage important biomolecules [7]. Damage of nucleic acids may trigger cancer development. In general, it is considered that the use of antioxidants prevents or retards the appearance of diverse diseases, including cancer, although le Gal et al. [8] reported that increased intracellular antioxidant activity may induce tumour cell survival. EOs have been demonstrated to possess antioxidant and antiproliferative properties which may contribute to the development of new chemotherapeutic drugs in the future [9].

The Myrtaceae eucalyptus group comprises four genera: Angophora Cav., Arillastrum (Brongniart \& Gris) Pancher ex Baillon, Corymbia K. D. Hill \& L.A.S. Johnson, and Eucalyptus L'Herit [10,11]. Despite this classification, it is common to designate as Eucalyptus several species of the four genera [12]. The eucalyptus group includes around 900 species and subspecies (Brooker and Kleinig in [13]). Species of the genus Eucalyptus are well adapted to diverse edaphoclimatic conditions, show rapid growth, and are easy to cultivate. Hence the genus Eucalyptus, originally from Australia, is widespread all over the world. Eucalyptus is mainly cultivated for obtaining cellulose, wood, gum, and EOs. The latter is obtained from the leaves and used in medicine, perfumery, and the food industry [14].

The recent compilation by Dhakad et al. [15] shows that Eucalyptus spp. leaf EOs possess biological and pharmacological properties, namely antimicrobial, antidiabetic, anthelmintic, antiviral, antihistaminic, anti-inflammatory, antimalarial, antioxidant, cytotoxic, larvicidal, nerve blocking, and pain-relieving activity, and are also useful for the relief of respiratory diseases and for wound healing. Eucalyptus EOs also possess activities as insecticides, pesticides, and nematicides [15-17].

Eucalyptus leaf essential oils are usually dominated by monoterpenes and sesquiterpenes. Nevertheless, their relative amounts or the ratio between them may differ according to species and varieties. Even within the same variety, the chemical composition may change depending on the geographical origin [12]. This highlights the importance of the knowledge of chemical composition since it will determine the bioactivity of each EO.

In the present work, the antioxidant, antimicrobial, and antiproliferative activities of EOs from Corymbia citriodora, Eucalyptus dives, Eucalyptus globulus, Eucalyptus delegatensis subsp. tasmaniensis, Eucalyptus pauciflora, Eucalyptus radiata, Eucalyptus smithii, Eucalyptus urophylla, and Eucalyptus viminalis (all from Portugal) were evaluated.

\section{Materials and Methods}

\subsection{Plant Material, EO Extraction, and Composition Analysis}

EOs were isolated from fresh aerial parts, collected during the vegetative phase in Portugal (Table 1), and their composition determined as previously described [18].

\subsubsection{Isolation of the Essential Oils}

The essential oils were isolated by hydrodistillation for $3 \mathrm{~h}$ using a Clevenger-type apparatus according to the European Pharmacopoeia method [19]. The isolation procedure was run at a distillation rate of $3 \mathrm{~mL} / \mathrm{min}$, and the essential oils were stored at $-20{ }^{\circ} \mathrm{C}$ in the dark until analysis. 


\subsubsection{Gas Chromatography (GC)}

Gas chromatographic analyses were performed using a Perkin Elmer Autosystem XL gas chromatograph (Perkin Elmer, Shelton, CT, USA) equipped with two flame ionization detectors (FIDs), a data handling system, and a vaporizing injector port into which two columns of different polarities were installed: a DB-1 fused-silica column (100\% dimethylpolysiloxane, $30 \mathrm{~m} \times 0.25 \mathrm{~mm}$ i.d., film thickness $0.25 \mu \mathrm{m}$; J \& W Scientific Inc., Folsom, CA, USA) and a DB-17HT fused-silica column ((50\%-phenyl)-methylpolysiloxane, $30 \mathrm{~m} \times 0.25 \mathrm{~mm}$ i.d., film thickness $0.15 \mu \mathrm{m}$; J \& W Scientific Inc.). The oven temperature was programmed to $45-175{ }^{\circ} \mathrm{C}$, increasing at $3{ }^{\circ} \mathrm{C} / \mathrm{min}$, subsequently increased to $300^{\circ} \mathrm{C}$ at to $15^{\circ} \mathrm{C} / \mathrm{min}$, and then maintained isothermal for $10 \mathrm{~min}$; injector and detector temperatures were $280^{\circ} \mathrm{C}$ and $300^{\circ} \mathrm{C}$, respectively. The carrier gas, hydrogen, was adjusted to a linear velocity of $30 \mathrm{~cm} / \mathrm{s}$. The samples were injected using a split sampling technique, ratio 1:50. The volume of injection was $0.1 \mu \mathrm{L}$ of a distilled $n$-pentane-oil solution (1:1). The percentage composition of the oils was computed by the normalization method from the GC peak areas, calculated as a mean value of two injections from each oil, without response factors.

\subsubsection{Gas Chromatography-Mass Spectrometry (GC-MS)}

The GC-MS unit consisted of a Perkin Elmer Autosystem XL gas chromatograph, equipped with DB-1 fused-silica column $(30 \mathrm{~m} \times 0.25 \mathrm{~mm}$ i.d., film thickness $0.25 \mu \mathrm{m}$; J \& W Scientific, Inc.), and interfaced with Perkin-Elmer Turbomass mass spectrometer (software version 5.4.2.1617, PerkinElmer, Shelton, CT, USA). Injector and oven temperatures were as above; transfer line temperature, $280^{\circ} \mathrm{C}$; ion source temperature, $220^{\circ} \mathrm{C}$; carrier gas, helium, adjusted to a linear velocity of $30 \mathrm{~cm} / \mathrm{s}$; split ratio, 1:40; ionization energy, $70 \mathrm{eV}$; scan range, 40-300 u; scan time, $1 \mathrm{~s}$. The identity of the components was assigned by comparison of their retention indices, relative to $C_{9}-C_{17} n$-alkane indices, and GC-MS spectra from a laboratory-made library based upon the analyses of reference oils, laboratory-synthesized components, and commercial available standards.

\subsection{Determination of Antioxidant Activity}

Antioxidant activity was determined with 2,2'-azino-bis(3-ethylbenzothiazoline-6-sulphonic acid) $\left(\mathrm{ABTS}^{+\bullet}\right)$ free radical scavenging activity and oxygen radical absorbance capacity (ORAC) methods. For the ABTS method, the preformed radical monocation of $\mathrm{ABTS}^{+} \bullet$ was generated by dissolving ABTS in water $(7 \mathrm{mM})$, adding potassium persulfate $(2.45 \mathrm{mM}$, final concentration), and allowing the mixture to stand overnight in the dark at room temperature. Before the assay, the ABTS ${ }^{+\bullet}$ solution was diluted with ethanol to obtain a solution with absorbance of 0.70 at $734 \mathrm{~nm}$ [20]. For the assay, $10 \mu \mathrm{L}$ of sample were added to $1000 \mu \mathrm{L}$ of $\mathrm{ABTS}^{+} \bullet$ solution and left to stand for 6 min, after which the absorbance was read spectrophotometrically at $734 \mathrm{~nm}$. For the control, the volume of sample was replaced by ethanol. The antioxidant activity of each sample was calculated as scavenging effect $\%(I A \%$, Inhibitory Activity Percentage $)=\left[\left(\mathrm{A}_{0}-\mathrm{A}_{1}\right) / \mathrm{A}_{0}\right] \times 100$, where $\mathrm{A}_{0}$ is the absorbance of the control, and $A_{1}$ is the absorbance of the sample. The same procedure was repeated using diverse concentrations of Trolox (6-hydroxy-2,5,7,8-tetramethylchroman-2-carboxylic acid) [21]. The values obtained with the samples were compared with the curve for several Trolox concentrations and the final results given as $\mu \mathrm{mol}$ Trolox equivalent (TE)/g EOs. Tests were carried out in triplicate.

For the ORAC assay, fluorescein (FL) was used as fluorescent probe [22]. Briefly, in each well $150 \mu \mathrm{L}$ of fluorescein working solution and $25 \mu \mathrm{L}$ of the previously diluted sample, blank (75 mM phosphate buffer), or standard (Trolox) were added. The plate was covered with a lid and incubated in the preheated $\left(37^{\circ} \mathrm{C}\right)$ BioTek Synergy ${ }^{\mathrm{TM}} 4$ Hybrid Microplate Reader (BioTek, Swindon, UK) for $10 \mathrm{~min}$ after shaking for $3 \mathrm{~min}$. Then 2,2'-Azobis-2-methyl-propanimidamide dihydrochloride (AAPH) was added to each well of the plate, except for the control and blank wells. The final volume of the assay was $200 \mu \mathrm{L}$. The fluorescence was read every minute for $90 \mathrm{~min}$ at $485 \mathrm{~nm}$ excitation and $527 \mathrm{~nm}$ emissions. ORAC values were calculated according to [23]. Briefly, the net area under the curve 
(AUC) of the standard (Trolox) and samples was calculated. The standard curve was obtained by plotting Trolox concentrations against the average net AUC of the measurements for each concentration. Final ORAC values were calculated using the regression equation between Trolox concentration and the net AUC and were expressed as $\mu \mathrm{mol} \mathrm{TE/g} \mathrm{EO} \mathrm{[24].} \mathrm{Tests} \mathrm{were} \mathrm{carried} \mathrm{out} \mathrm{in} \mathrm{triplicate.}$

\subsection{Determination of Antibacterial Activity}

Antibacterial activity was determined against two strains of Streptococcus pneumoniae D39 and TIGR4, and Haemophilus influenza DSM 9999. Bacterial strains were kept at $-70{ }^{\circ} \mathrm{C}$ in brain heart infusion (BHI) (Oxoid) supplemented with glycerol (final concentration 25\%, $v / v$ ) until use. The cultures were recovered from freezing by growth in brain heart infusion supplemented with $5 \%(v / v)$ horse blood at $37^{\circ} \mathrm{C}$ in microaerophilic conditions. Prior to the assay bacterial cultures were grown in Columbia agar (Oxoid) plates supplemented with $5 \%(v / v)$ horse blood at $37^{\circ} \mathrm{C}$ in microaerophilic conditions for $24 \mathrm{~h}$. From this plate a suspension with a turbidity value corresponding to 0.5 in the McFarland scale was prepared. From this suspension $0.1 \mathrm{~mL}$ was transferred to a new Columbia agar plate supplemented with $5 \%(v / v)$ horse blood. Sterile filter paper discs of $6 \mathrm{~mm}$ (Oxoid) were distributed on the agar surface and $3 \mu \mathrm{L}$ of each essential oil was dispensed in the paper discs. Tea tree essential oil with 38\% terpinen-4-ol (Optima Healthcare Ltd., Bradford, UK) was included as reference. Sterile $n$-propanol (essential oil solvent) and the antibiotic chloramphenicol (30 $\mu \mathrm{g} / \mathrm{disk})$ were used as control. Inhibition zones were evaluated after $24 \mathrm{~h}$ at $37^{\circ} \mathrm{C}$ in microaerophilic conditions. The assays were done in triplicate.

The minimum inhibitory concentration (MIC) for the tested EOs was determined using a microdilution method [6,25]. Concentrations ranging from 0 to $0.4 \mathrm{mg} / \mathrm{mL}$ with increments of $0.05 \mathrm{mg} / \mathrm{mL}$ were tested. Three replicates for each bacterium were used. The recovery of the viability of each bacterium was evaluated, and the minimum concentration at which no viability was observed was considered as the minimum bactericidal concentration (MBC).

\subsection{Determination of Antiproliferative Activity}

Human leukaemic cell line THP-1 cells were cultured in Dulbecco's Modified Eagle Medium (DMEM) supplemented with $10 \%(v / v)$ foetal bovine serum, $1 \%(v / v)$ nonessential amino acids, $100 \mathrm{U} / \mathrm{mL}$ penicillin, and $100 \mathrm{\mu g} / \mathrm{mL}$ streptomycin, according to [24]. They were incubated at $37^{\circ} \mathrm{C}$ in a humidified $5 \% \mathrm{CO}_{2}$ atmosphere.

The growth inhibitory effect of EOs was measured using the 3-(4,5-dimethylthiazol-2-yl) 2,5-diphenyltetrazolium bromide (MTT) assay [26]. THP-1 cells were seeded in 96-well plate at $5 \times 10^{3}$ cells/well and submitted to different EO concentrations (10-500 $\mu \mathrm{g} / \mathrm{mL}$ ). All samples were dissolved in dimethyl-sulfoxide (DMSO). The solvent concentration in the incubation medium never exceeded $0.5 \%$. Control cultures had the equivalent concentration of DMSO. After treatment, cells were incubated $(1 \mathrm{~h})$ in the usual culture conditions after addition of the same volume of medium containing MTT $(2 \mathrm{mg} / \mathrm{mL})$. After this period, $150 \mu \mathrm{L} \mathrm{HCl}(0.1 \mathrm{M})$ in isopropanol was added to dissolve the blue formazan crystals formed owing to the reduction of MTT. Absorbance at $570 \mathrm{~nm}$ using a background reference wavelength of $630 \mathrm{~nm}$ was measured. Antiproliferative activity was expressed as the mean absorbance values for the negative control (DMSO-treated cells) standardized as $100 \%$ absorbance (i.e., no growth inhibition) and results were expressed as absorbance (\% of control) versus essential oil concentration [24].

\subsection{Statistical Analysis}

Data were analysed by one-way analysis of variance (ANOVA) using IBM SPSS Statistics version 23 (IBM, Armonk, NY, USA). Tukey's test was used to determine the difference at 5\% significance level. 
Table 1. Studied Corymbia and Eucalyptus species. Currently accepted scientific names for plant species, arranged in alphabetic order of the corresponding plant family, sampling year, plant part used for hydrodistillation, plant source, essential oil yield, and main essential oil components ( $\geq 10 \%)$

\begin{tabular}{|c|c|c|c|c|c|c|c|}
\hline Family/Species & & Code & SY & PP & $\mathrm{CP}$ & Yield $(\%, v / w)$ & Main Components $(\geq 10 \%)$ * \\
\hline \multicolumn{8}{|l|}{ Myrtaceae } \\
\hline Current accepted species name & Synonyms & & & & & & \\
\hline $\begin{array}{c}\text { Corymbia citriodora (Hook.) K.D.Hill \& } \\
\text { L.A.S.Johnson }{ }^{\mathrm{a}}\end{array}$ & $\begin{array}{l}\text { Corymbia citriodora subsp. variegata (F.Muell.) A.R.Bean \& } \\
\text { M.W.McDonald, Corymbia variegata (F.Muell.) K.D.Hill \& } \\
\text { L.A.S.Johnson, Eucalyptus citriodora Hook., Eucalyptus maculata } \\
\text { var. citriodora (Hook.) F.M.Bailey, Eucalyptus melissiodora Lindl., } \\
\text { Eucalyptus variegata F.Muell. }\end{array}$ & $\mathrm{Cc}$ & 2009 & FV & MEE & 0.86 & $\begin{array}{l}\text { citronellal 36, isopulegol 13, } \\
\text { citronellol 12, 1,8-cineole } 11\end{array}$ \\
\hline Eucalyptus dives Schauer ${ }^{\text {a }}$ & Eucalyptus amygdalina var. latifolia H.Deane \& Maiden & Ed & 2009 & FV & MEE & 3.30 & $\begin{array}{c}\text { piperitone } 40, \alpha \text {-phellandrene } 19 \text {, } \\
\text { p-cymene } 19\end{array}$ \\
\hline Eucalyptus globulus Labill. ${ }^{\mathrm{b}}$ & $\begin{array}{l}\text { Eucalyptus gigantea Dehnh., Eucalyptus glauca A.Cunn. ex DC., } \\
\text { Eucalyptus globulosus St.-Lag., Eucalyptus globulus subsp. } \\
\text { globulus, Eucalyptus maidenii subsp. globulus (Labill.) J.B.Kirkp., } \\
\text { Eucalyptus perfoliata Desf., Eucalyptus pulverulenta Link }\end{array}$ & Eg & 2009 & $\mathrm{FV}$ & Lisbon & 2.15 & 1.8-Cineole $64, \alpha$-pinene 20 \\
\hline $\begin{array}{l}\text { Eucalyptus delegatensis subsp. } \\
\text { tasmaniensis Boland }{ }^{\mathrm{c}}\end{array}$ & $\begin{array}{l}\text { Eucalyptus gigantea Hook.f., Eucalyptus risdonii var. elata Benth., } \\
\text { Eucalyptus tasmanica Blakely }\end{array}$ & Edt & 2011 & FV & MEE & 0.52 & $\begin{array}{c}\text { Limonene } 36, p \text {-cymene } 11 \\
\text { 1,8-cineole } 10\end{array}$ \\
\hline Eucalyptus pauciflora Sieber ex Spreng a & $\begin{array}{l}\text { Eucalyptus coriacea A.Cunn. ex Schauer, Eucalyptus coriacea var. } \\
\text { alpina Benth, Eucalyptus pauciflora var. alpina Ewart, Eucalyptus } \\
\text { pauciflora subsp. pauciflora, Eucalyptus phlebophylla F.Muell. ex } \\
\text { Miq., Eucalyptus submultiplinervis Miq., Eucalyptus sylvicultrix } \\
\text { F.Muell. ex Benth. }\end{array}$ & Ep & 2009 & FV & MEE & 0.84 & $\alpha$-pinene 82 \\
\hline Eucalyptus radiata A.Cunn. ex DC. ${ }^{a}$ & $\begin{array}{l}\text { Eucalyptus amygdalina var. radiata (A.Cunn. ex DC.) Benth., } \\
\text { Eucalyptus australiana R.T.Baker \& H.G.Sm., Eucalyptus } \\
\text { australiana var. latifolia R.T.Baker \& H.G.Sm., Eucalyptus } \\
\text { phellandra R.T.Baker \& H.G.Sm., Eucalyptus radiata var. } \\
\text { australiana (R.T.Baker \& H.G.Sm.) Blakel, Eucalyptus radiata } \\
\text { subsp. radiata, Eucalyptus radiata var. subexserta Blakely }\end{array}$ & Er & 2009 & $\mathrm{FV}$ & MEE & 5.55 & 1,8-cineole 48, p-cymene 13 \\
\hline Eucalyptus smithii R.T. Baker a & Eucalyptus viminalis var. pedicellaris H.Deane \& Maiden & Es & 2009 & FV & MEE & 2.80 & 1,8-cineole 83 \\
\hline Eucalyptus urophylla S. T. Blake ${ }^{a}$ & No synonyms recorded & $\mathrm{Eu}$ & 2009 & $\mathrm{FV}$ & MEE & 0.86 & $\alpha$-phellandrene $45,1,8$-cineole 23 \\
\hline Eucalyptus viminalis Labill. ${ }^{a}$ & $\begin{array}{l}\text { Eucalyptus angustifolia Desf. ex Link, Eucalyptus gunnii Miq., } \\
\text { Eucalyptus huberiana Naudin, Eucalyptus viminalis var. huberiana } \\
\text { (Naudin) N.T.Burb., Eucalyptus viminalis var. rhynchocorys } \\
\text { Maiden, Eucalyptus viminalis subsp. viminalis }\end{array}$ & Ev & 2009 & FV & MEE & 1.10 & $\begin{array}{l}\text { 1,8-cineole } 46, \alpha \text {-pinene } 13 \\
\quad \gamma \text {-terpinene } 12\end{array}$ \\
\hline
\end{tabular}




\section{Results and Discussion}

\subsection{Antioxidant Activity}

The antioxidant activity of the EO was determined with an electron reaction-based method (the ABTS+ method) and a hydrogen reaction-based method (the ORAC method). With the TEAC method, Cc EO showed significantly higher antioxidant activity (5.08 $\mu \mathrm{mol} \mathrm{TE} / \mathrm{g}$ EO) than Eucalyptus EOs (Table 2). The lowest antioxidant activity was observed with Eg, Ep, Er and Es EOs, without significant differences among them. The activities ranged from 0.10 in Es to $0.30 \mu \mathrm{mol} \mathrm{TE} / \mathrm{g}$ in Eg EO. Cc EO showed the highest scavenging peroxyl radical activity (148.55 $\mu$ mol TE/g EO) along with Ev

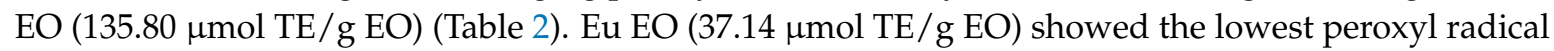
scavenging activity.

Results for the essential oils of $\mathrm{Cc}_{\mathrm{c}}$ and Es are in agreement with those previously reported by Luis et al. [28] for these species. In Luis et al. [28] study, citronellal (78\%) was the main component for Corymbia citriodora EO, and 1,8-cineole (82\%) dominated in Eucalyptus smithii EO.

Citronellal shows moderate antioxidant activity due to its limited capacity to scavenge free radicals [29]. The antioxidant activity of citronellal may be related to one unpaired electron from the molecule allylic hydrogen of both $\mathrm{CH}_{3}$ or $\mathrm{CH}_{2}$ (Figure 1) that by resonance stabilize the radical formed after the reaction. Nevertheless, Wojtunik et al. [30] considered that only the presence of conjugation of $\pi$ bonds would allow a resonance-stabilized structure. However, essential oils are complex mixtures and the antioxidant activity cannot be assigned to only one compound. The different constituents of EOs may act synergistically or antagonistically, leading to an overall activity that results from the interaction among several compounds. Ciesla et al. [29] studied the capacity of binary mixtures of some common EO terpenoids, for scavenging DPPH free radicals. They reported an antagonistic effect between citronellal and 1,8-cineole, both present in Cc EO. Nonetheless, the interaction of citronellal with other constituents could trigger a synergistic effect, responsible for the high level of activity observed in Cc EO. Antagonism was also observed by Ciesla et al. [29] for the binary mixture of 1,8-cineole and $p$-cymene. These constituents were the major Er EO compounds (Table 1). Eg, Ep, Er, and Es EOs, which showed the lowest free radical scavenger activities, had 1,8-cineole, $\alpha$-pinene, and $p$-cymene as major constituents. These monoterpenes were previously reported as poor scavengers of DPPH free radicals [31]. $\gamma$-Terpinene, one of the main constituents of Ev EO, is considered a good free radical scavenger $[29,32]$, possibly due to the delocalization of the unpaired electron along the molecule, owing to the two allylic hydrogens that can stabilize the resonance-structures (Figure 1). Moreover, the binary mixture of $\gamma$-terpinene and 1,8-cineole (another major constituent of Ev EO) did not produce any significant effects. Despite the presence of an allylic hydrogen in $p$-cymene in conjugation with an aromatic ring, its abstraction from the molecule can be difficult due to steric hindrances, because hydrogen is hidden by the two $\mathrm{CH}_{3}$ groups as well as by the aromatic ring (Figure 1).

Table 2. The activity of essential oils of Corymbia citriodora and Eucalyptus spp. for scavenging ABTS+ and peroxyl radicals.

\begin{tabular}{ccc}
\hline Sample Code $^{*}$ & TEAC $(\mu \mathrm{mol} \mathrm{TE} / \mathrm{g}$ Essential Oil $)$ & ORAC $(\mu \mathrm{mol}$ TE/g Essential Oil $)$ \\
\hline Cc & $5.08 \pm 0.08^{\mathrm{a}}$ & $148.55 \pm 7.76^{\mathrm{a}}$ \\
Ed & $0.53 \pm 0.08^{\mathrm{d}}$ & $96.83 \pm 7.76^{\mathrm{bc}}$ \\
Edt & $1.27 \pm 0.08^{\mathrm{c}}$ & $73.31 \pm 7.76^{\mathrm{c}}$ \\
Eg & $0.30 \pm 0.08^{\mathrm{e}}$ & $87.29 \pm 7.76^{\mathrm{bc}}$ \\
Ep & $0.17 \pm 0.08^{\mathrm{e}}$ & $99.70 \pm 7.76^{\mathrm{b}}$ \\
Er & $0.21 \pm 0.08^{\mathrm{e}}$ & $112.33 \pm 7.76^{\mathrm{b}}$ \\
Es & $0.10 \pm 0.08^{\mathrm{e}}$ & $93.66 \pm 7.76^{\mathrm{bc}}$ \\
Eu & $0.68 \pm 0.08^{\mathrm{d}}$ & $37.14 \pm 7.76^{\mathrm{d}}$ \\
Ev & $1.62 \pm 0.08^{\mathrm{b}}$ & $135.80 \pm 7.76^{\mathrm{a}}$
\end{tabular}

* For sample code see Table 1. Values in the same column followed by the same letter are not significant by Tukey's multiple range test $(p<0.05)$. 
<smiles>C=C(C)C=C(C)CC(C)CC(C=O)CC(C)CC(C)CC=O</smiles><smiles>CC1=CCC(C(C)C)C=C1C(C)C</smiles>

Figure 1. Chemical structure of citronellal, $\gamma$-terpinene and $p$-cymene. Citronellal and $\gamma$-terpinene representing the allylic hydrogens. The radical formed can be stabilized by resonance.

\subsection{Antibacterial Activity}

Essential oils of thyme, tea tree, peppermint, anise, fennel, and eucalyptus may be used for the treatment of simple respiratory tract diseases [4]. Eucalyptus EOs have been used in the treatment of bronchitis, cold, cough, and in the symptomatic relief of catarrh of the upper respiratory tract [4]. Tea tree EO has been used for treating some respiratory infections, such as bronchitis, cold, and influenza [4].

S. pneumoniae, H. influenzae, and Staphylococcus aureus have been associated with community-acquired pneumonia, along with the less common Pseudomonas aeruginosa, Pneumocystis jirovecii, Moraxella catarrhalis, and other Gram-negative bacteria [33].

In the present work the capacity for inhibiting the growth of two strains of S. pneumoniae (D39 and TIGR4) and H. influenzae (DSM 9999) by Cc, Ed, Eg, Es and Ev EOs was evaluated and compared with that of tea tree EO and the antibiotic chloramphenicol (Table 3).

Table 3. The antibacterial activities of Corymbia citriodora and Eucalyptus spp. EOs expressed as inhibition zones, in $\mathrm{mm}$. Tea tree oil and chloramphenicol were used as references.

\begin{tabular}{|c|c|c|c|}
\hline \multirow{2}{*}{ Essential Oil } & \multicolumn{3}{|c|}{ Microorganism $^{\dagger}$} \\
\hline & S. pneumoniae D39 & S. pneumoniae TIGR 4 & H. influenza DSM 9999 \\
\hline Tea tree & $14.00 \pm 1.73^{\mathrm{a}}$ & $12.25 \pm 1.89^{a}$ & $11.75 \pm 2.36^{\mathrm{a}}$ \\
\hline C. citriodora & $11.33 \pm 2.03^{a}$ & $8.00 \pm 1.41^{b}$ & $11.25 \pm 0.50^{\mathrm{a}}$ \\
\hline E. dives & $13.67 \pm 2.08^{a}$ & NI & $10.00 \pm 0.81^{\mathrm{a}}$ \\
\hline E. globulus & $12.00 \pm 1.73^{\mathrm{a}}$ & $8.75 \pm 0.95^{b}$ & $13.00 \pm 1.82^{\mathrm{a}}$ \\
\hline E. smithii & $14.00 \pm 1.73^{\mathrm{a}}$ & $8.00 \pm 0.81^{b}$ & $12.00 \pm 2.16^{\mathrm{a}}$ \\
\hline E. viminalis & $14.66 \pm 1.52^{\mathrm{a}}$ & $6.66 \pm 0.57^{\mathrm{b}}$ & $11.75 \pm 1.50^{\mathrm{a}}$ \\
\hline Chloramphenicol & $22.33 \pm 4.04^{b}$ & $21.00 \pm 1.15^{c}$ & $24.00 \pm 0.81^{b}$ \\
\hline
\end{tabular}

+ Data represent the mean \pm standard deviation of three replicates. Data with the same superscript letter are not significantly different $(p>0.05)$. NI: No inhibition. 
All essential oils showed poor antibacterial activity in comparison with the antibiotic chloramphenicol, however differences could be observed among the EOs and bacterial strains (Table 3). For example, all EOs were less effective against $S$. pneumoniae TIGR4 in comparison with S. pneumoniae D39. For S. pneumoniae TIGR 4, tea tree EO showed better activity than Myrtaceae EOs, and the strain was even resistant to Ed EO. For H. influenzae, no significant differences $(p>0.05)$ were observed between the antibacterial activity-assayed Myrtaceae EOs (Table 3).

The MIC and MBC values were determined for Es, Eg, and tea tree EOs (Table 4). The lowest MIC and MBC values were observed for Eg EO against S. pneumoniae TIGR 4, with values of 0.015 and $0.05 \mathrm{mg} / \mathrm{mL}$, respectively. Both S. pneumoniae strains showed a similar MIC and MBC for the tea tree EO, namely 0.025 and $0.1 \mathrm{mg} / \mathrm{mL}$, respectively. However, for the Es EO S. pneumoniae D39 showed a similar MIC value to S. pneumoniae TIGR 4, but the MBC value was the double of that of S. pneumoniae TIGR 4, showing an MBC of $0.3 \mathrm{mg} / \mathrm{mL}$ in contrast to TIGR 4 that showed an MBC of $0.15 \mathrm{mg} / \mathrm{mL}$ (Table 4). Such differences may be associated with serotype differences between the strains. Moreover, Eg EO, that in the diffusion agar test showed a very weak activity against S. pneumoniae TIGR 4, displayed an efficient activity in the microdilution assay, even in comparison with tea tree EO. These differences may be related to its low diffusion ability. Intriguing was the resistant behaviour of $H$. influenza that was able to growth at the highest EO concentration tested $(0.4 \mathrm{mg} / \mathrm{mL})$. Eg EO showed a better activity against $S$. pneumoniae, that can be related with its richness in 1,8-cineole and $\alpha$-pinene. In addition, 1,8-cineole prevents the growth of other microorganisms, but when in association with other terpenes in an essential oil, such as camphene, $\alpha$-pinene, globulol and limonene, it was more efficient against S. aureus, methicillin-resistant S. aureus (MRSA), Escherichia coli and Candida albicans, and also biofilms of MRSA and P. aeruginosa [34].

Table 4. Minimum inhibitory concentration (MIC) and minimum bactericidal concentration (MBC) values for Eucalyptus and tea tree EOs $\S$.

\begin{tabular}{ccccccc}
\hline \multirow{2}{*}{ Microorganism } & \multicolumn{2}{c}{ Tea Tree } & \multicolumn{2}{c}{ E. globulus } & \multicolumn{2}{c}{ E. smithii } \\
\cline { 2 - 7 } & MIC $^{\dagger}$ & MBC $^{\dagger}$ & MIC & MBC & MIC & MBC \\
\hline S. pneumoniae D39 & 0.025 & 0.1 & 0.1 & 0.15 & 0.1 & 0.30 \\
S. pneumoniae TIGR 4 & 0.025 & 0.1 & 0.015 & 0.05 & 0.1 & 0.15 \\
H. influenza DSM 9999 & $>0.4$ & $>0.4$ & $>0.4$ & $>0.4$ & $>0.4$ & $>0.4$ \\
\hline \multicolumn{2}{c}{ \& Data repres }
\end{tabular}

\subsection{Antiproliferative Activity}

The antiproliferative activities of Corymbia and Eucalyptus species EOs were studied with the THP-1 cell line (human acute monocytic leukaemia) using the MTT assay. Cells were incubated to increasing amounts of EOs for $24 \mathrm{~h}$ and $96 \mathrm{~h}$ (Figures 2 and 3).

EOs decreased viability of THP-1 cells in a dose-dependent manner. After one day, a great difference was observed between the antiproliferative activity of Eg and Es EOs and the other EOs, particularly at $50 \mu \mathrm{g} / \mathrm{mL}$. Hence, Eg and Es EOs possessed the lowest antiproliferative activities. After $96 \mathrm{~h}$ incubation of THP1 cells with EOs, the differences were more evident for lower concentrations ( 10 and $25 \mu \mathrm{g} / \mathrm{mL}$ ). At $25 \mu \mathrm{g} / \mathrm{mL}$, it was possible to distinguish two EOs (Er and $\mathrm{Ev}$ ) with significantly higher antiproliferative activity than the remaining EOs. At $50 \mu \mathrm{g} / \mathrm{mL}$, these differences disappeared, because almost all EOs showed survival percentages $<20 \%$. The exceptions were Eg and Es EOs, that showed survival percentages above $>70 \%$, at $50 \mu \mathrm{g} / \mathrm{mL}$. The main constituents of Eg EO were 1,8-cineole (64\%) and $\alpha$-pinene (20\%), and in Es EO, 1,8-cineole represented $80 \%$ of the total EO (Table 1). The major components of the Er and Ev EOs also included 1,8-cineole (48 and 46\%, respectively), and other components such as $p$-cymene (13\%) for Er and $\alpha$-pinene (20\%), and $\gamma$-terpinene (12\%) for Ev EOs (Table 1). The results suggested that 1,8-cineole has low antiproliferative activity on the THP- 1 leukaemia cell line, although in the presence of $p$-cymene or $\gamma$-terpinene, the antiproliferative activity increased. 
The weak antiproliferative activity of 1,8-cineole, $p$-cymene, $\alpha$-pinene has been reported [35], despite these monoterpenes having not been assayed together. Results may suggest a potential synergistic effect between the following pairs: 1,8-cineole and p-cymene, and 1,8-cineole with $\gamma$-terpinene.

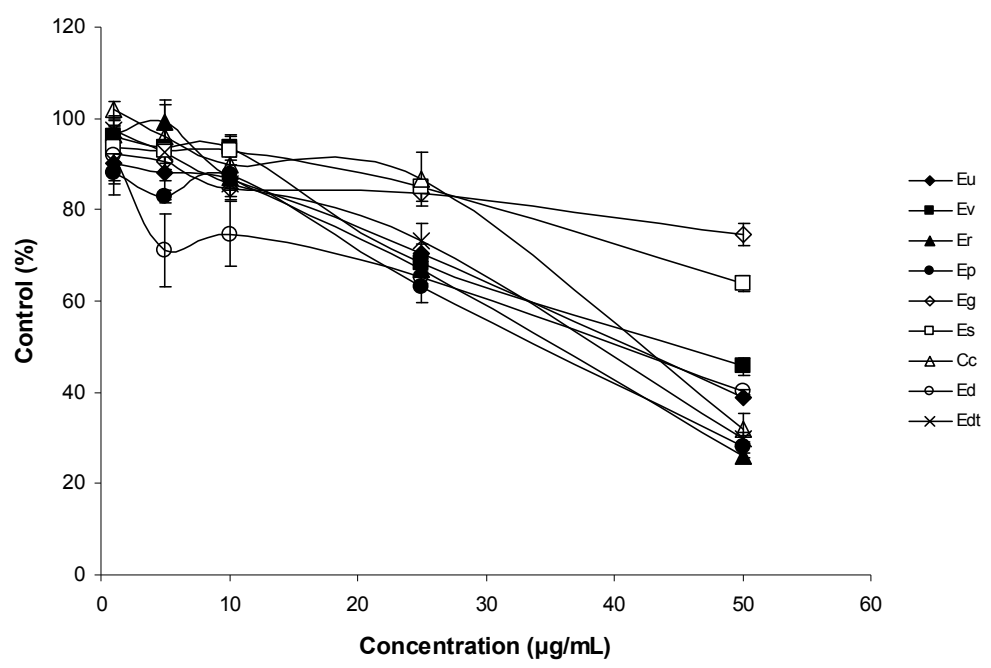

Figure 2. Antiproliferative activity of the EOs on THP-1 cell line after $24 \mathrm{~h}$ of exposure. The mean absorbance values for the negative control (dimethyl-sulfoxide (DMSO)-treated cells) were standardized as $100 \%$ absorbance (i.e., no growth inhibition) and results were displayed as absorbance ( $\%$ of control) versus essential oil concentration.

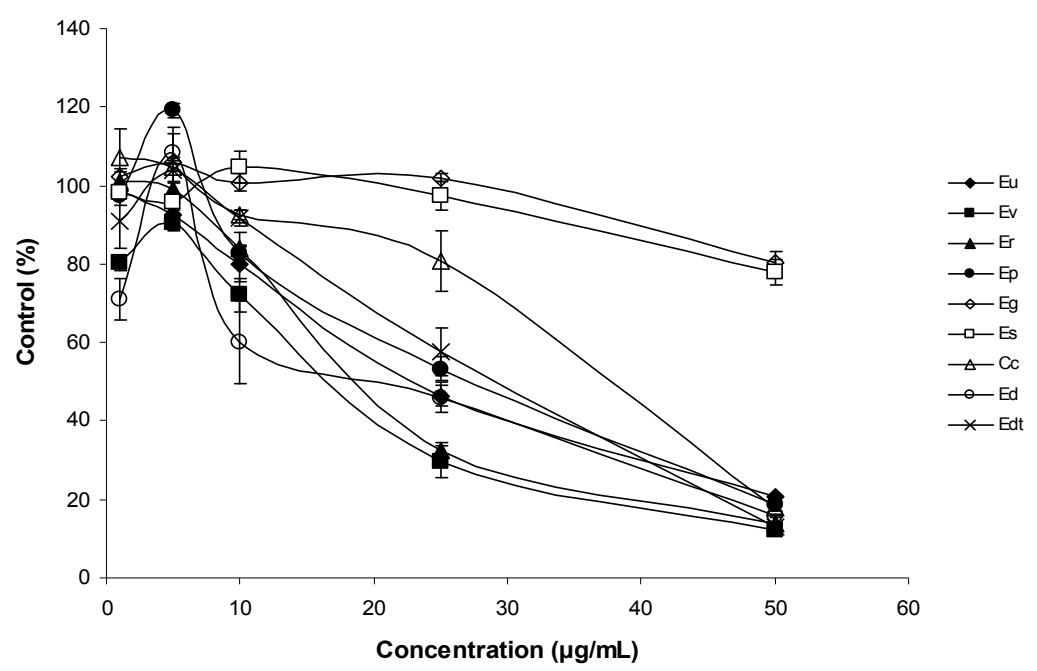

Figure 3. Antiproliferative activity of EOs on THP-1 cell line after $96 \mathrm{~h}$ of exposure. The mean absorbance values for the negative control (DMSO-treated cells) were standardized as $100 \%$ absorbance (i.e., no growth inhibition) and results were displayed as absorbance (\% of control) versus essential oil concentration.

\section{Conclusions}

The highest scavenging of ABTS+ and peroxyl free radicals was observed in Cc and Ev EOs, and the lowest was detected in Eu EO. All essential oils were less effective against S. pneumoniae TIGR4 than against the D39 strain. MIC and MBC values showed that Eg EO is promising for the treatment of S. pneumoniae infections. EOs displayed low diffusion capacity and the antibacterial activity screening through microdilution test would be more appropriate. H. influenzae was the respiratory pathogen that 
showed the highest resistance to all EOs including that of tea tree. Eg and Es EOs showed the lowest antiproliferative activities on THP-1 cells. After $96 \mathrm{~h}$ incubation, the Er and Ev EOs showed the highest antiproliferative activity against THP-1 cells. Although further assays are required, the results suggest that the antiproliferative activity is challenged by the combination of 1,8 -cineole with $p$-cymene or with $\gamma$-terpinene. Despite their specific bioactivities, none of the assayed EOs showed simultaneously good antibacterial, antioxidant, and antiproliferative capacity.

Supplementary Materials: The following are available online at www.mdpi.com/2305-6320/5/3/61/s1, Table S1: Percentage composition of the essential oil isolated from Eucalyptus delegatensis subsp. tasmaniensis Boland, previously included in the study of Sena et al. [27] under the former name of E. gigantea.

Author Contributions: M.G.M., J.V. and A.C.F. conceived and designed the experiments; A.C.F. contributed to the chemical composition analysis of samples; C.G. and M.D.A. contributed to the antioxidant activity evaluation; S.L. carried out the antibacterial activities at CBMR/UAlg under the direction of M.L.F.; M.G.M., C.M. and I.C.-G. contributed to the work on antiproliferative activity. M.G.M., M.L.F., J.V. and A.C.F. contributed to the data handling. All authors have also contributed in writing the paper.

Funding: This study was partially funded by CESAM (UID/AMB/50017-POCI-01-0145-FEDER-007638), to FCT / MCTES through national funds (PIDDAC), and co-funding by the FEDER within the PT2020 Partnership Agreement and Compete 2020, and by the Fundação para a Ciência e a Tecnologia (FCT), under the projects UID/BIA/04325/2013-MEDTBIO, and UID/BIM/04773/2013 CBMR.

Acknowledgments: The authors acknowledge the Instituto da Conservação da Natureza e das Florestas (ICNF) and particularly Eng João Sanches (Mata Experimental do Escaroupim (MEE)) from the Centro Nacional de Sementes Florestais (CENASEF) for kindly allowing the sampling of all studied species from the MEE.

Conflicts of Interest: The authors declare no conflict of interest.

\section{References}

1. Mulu, W.; Yizengaw, E.; Alemu, M.; Mekonnen, D.; Hailu, D.; Ketemaw, K.; Abera, B.; Kibret, M. Pharyngeal colonization and drug resistance profiles of Morraxella catarrhalis, Streptococcus pneumoniae, Staphylococcus aureus, and Haemophilus influenzae among HIV infected children attending ART clinic of felegehiwot referral hospital, Ethiopia. PLoS ONE 2018, 13, e0196722. [CrossRef] [PubMed]

2. Örtqvist, A.; Hedlund, J.; Kalin, M. Streptococcus pneumoniae: Epidemology, risk factors, and clinical features. Semin. Respir. Crit. Care Med. 2005, 26, 563-574. [CrossRef] [PubMed]

3. Brochot, A.; Guilbot, A.; Haddioui, L.; Roques, C. Antibacterial, antifungal, and antiviral effects of three essential oil blends. MicrobiologyOpen 2017, 6, e459. [CrossRef] [PubMed]

4. Horváth, G.; Ács, K. Essential oils in the treatment of respiratory tract diseases highlighting their role in bacterial infections and their anti-inflammatory action: A review. Flavour Fragr. J. 2015, 30, 331-341. [CrossRef]

5. Chouhan, S.; Sharma, K.; Guleria, S. Antimicrobial activity of some essential oils-Present status and future perspectives. Medicines 2017, 4, 58. [CrossRef] [PubMed]

6. Apolónio, J.; Faleiro, M.L.; Miguel, M.G.; Neto, L. No induction of antimicrobial resistance in Staphylococcus aureus and Listeria monocytogenes during continuous exposure to eugenol and citral. FEMS Microbiol. Lett. 2014, 354, 92-101. [CrossRef] [PubMed]

7. Ung, L.; Pattamatta, U.; Carnt, N.; Wilkinson-Berka, J.L.; Liew, G. Oxidative stress and reactive oxygen species: A review of their role in ocular disease. Clin. Sci. 2017, 131, 2865-2883. [CrossRef] [PubMed]

8. Le Gal, K.; Ibrahim, M.X.; wiel, C.; Sayin, V.I.; Akula, M.K.; Karlsson, C.; Dalin, M.G.; Akyürek, L.M.; Lindahl, P.; Nilsson, J.; et al. Antioxidants can increase melanoma metastasis in mice. Sci. Transl. Med. 2015, 7, 308re8. [CrossRef] [PubMed]

9. Blowman, K.; Magalhães, M.; Lemos, M.F.L.; Cabral, C.; Pires, I.M. Anticancer properties of essential oils and other natural products. Evid. Based Complement. Altern. Med. 2018, 3149362. [CrossRef] [PubMed]

10. Hill, K.D.; Johnson, L.A.S. Systematic studies in the eucalypts. 7. A revision of the bloodwoods, genus Corymbia (Myrtaceae). Telopea 1995, 6, 185-504. [CrossRef]

11. Brophy, J.J.; Forster, P.I.; Goldsack, R.J.; Hibbert, D.B. The essential oils of the yellow bloodwood eucalypts (Corymbia, section Ochraria, Myrtaceae). Biochem. Syst. Ecol. 1998, 26, 239-249. [CrossRef] 
12. Barbosa, L.C.A.; Filomeno, C.A.; Teixeira, R.R. Chemical variability and biological activities of Eucalyptus spp. essential oils. Molecules 2016, 21, 1671. [CrossRef] [PubMed]

13. Gilles, M.; Zhao, J.; An, M.; Agboola, S. Chemical composition and antimicrobial properties of essential oils of three Australian Eucalyptus species. Food Chem. 2010, 119, 731-737. [CrossRef]

14. Silva, S.M.; Abe, S.Y.; Murakami, F.S.; Frensch, G.; Marques, F.A.; Nakashima, T. Essential oils from different plant parts of Eucalyptus cinerea F. Muell. Ex Benth. (Myrtaceae) as a source of 1,8-cineole and their bioactivities. Pharmaceuticals 2011, 4, 1535-1550. [CrossRef] [PubMed]

15. Dhakad, A.; Pandey, V.V.; Beg, S.; Rawat, J.M.; Singh, A. Biological, medicinal and toxicological significance of Eucalyptus leaf essential oil: A review. J. Sci. Food Agric. 2018, 98, 833-848. [CrossRef] [PubMed]

16. Faria, M.S.; Barbosa, P.; Bennett, R.N.; Mota, M.; Figueiredo, A.C. Bioactivity against Bursaphelenchus xylophilus: Nematotoxics from essential oils, essential oils fractions and decoction waters. Phytochemistry 2013, 94, 220-228. [CrossRef] [PubMed]

17. Barbosa, P.; Faria, J.M.S.; Mendes, M.D.; Dias, L.S.; Tinoco, M.T.; Barroso, J.G.; Pedro, L.G.; Figueiredo, A.C.; Mota, M. Bioassays against Pinewood nematode: Assessment of a suitable dilution agent and screening for bioactive essential oils. Molecules 2012, 17, 12312-12329. [CrossRef] [PubMed]

18. Faria, J.M.S.; Sanches, J.; Lima, A.S.; Mendes, M.D.; Leiria, R.; Geraldes, D.A.; Figueiredo, A.C.; Trindade, H.; Pedro, L.G.; Barroso, J.G. Eucalyptus from Mata Experimental do Escaroupim (Portugal): Evaluation of the essential oil composition from sixteen species. Acta Hortic. 2011, 925, 61-66. [CrossRef]

19. Council of Europe (COE); European Directorate for the Quality of Medicines. European Pharmacopoeia, 6th ed.; Council of Europe (COE): Strasbourg, France, 2007.

20. Re, R.; Pellegrini, N.; Proteggente, A.; Pannala, A.; Yang, M.; Rice-Evans, C. Antioxidant activity applying an improved ABTS radical cation decolorization assay. Free Rad. Biol. Med. 1999, 26, 1231-1237. [CrossRef]

21. Antunes, M.D.C.; Dandlen, S.; Cavaco, A.M.; Miguel, G. Effects of postharvest application of 1-MCP and postcutting dip treatment on the quality and nutritional properties of fresh-cut kiwifruit. J. Agric. Food Chem. 2010, 58, 6173-6181. [CrossRef] [PubMed]

22. Ou, B.; Hampsch-Woodill, M.; Prior, R.L. Development and validation of an improved oxygen radical absorbance capacity assay using fluorescein as the fluorescent probe. J. Agric. Food Chem. 2001, 49, 4619-4626. [CrossRef] [PubMed]

23. Huang, D.; Ou, B.; Hampsch-Woodill, M.; Flanagan, J.A.; Prior, R.L. High-throughput assay of oxygen radical absorbance capacity (ORAC) using a multichannel liquid handling system coupled with a microplate fluorescence reader in 96-well format. J. Agric. Food Chem. 2002, 50, 4437-4444. [CrossRef] [PubMed]

24. Miguel, M.G.; Gago, C.; Antunes, M.D.; Megías, C.; Cortés-Giraldo, I.; Vioque, J.; Lima, A.S.; Figueiredo, A.C. Antioxidant and antiproliferative activities of the essential oils from Thymbra capitata and Thymus species grown in Portugal. Evid. Based Complement. Altern. Med. 2015, 2015, 851721. [CrossRef] [PubMed]

25. Faleiro, L.; Miguel, G.; Gomes, S.; Costa, L.; Venâncio, F.; Teixeira, A.; Figueiredo, A.C.; Barroso, J.A.; Pedro, L.G. Antibacterial and antioxidant activities of essential oils isolated from Thymbra capitata L. (Cav.) and Origanum vulgare L. J. Agric. Food Chem. 2005, 53, 8162-8168. [CrossRef] [PubMed]

26. Mosmann, T. Rapid colorimetric assay for cellular growth and survival: Application to proliferation and cytotoxicity assays. J. Immunol. Methods 1983, 65, 55-63. [CrossRef]

27. Sena, I.; Faria, J.M.S.; Sanches, J.; Trindade, H.; Pedro, L.G.; Barroso, J.G.; Figueiredo, A.C. Essential oil composition from twenty-six Eucalyptus taxa from Mata Experimental do Escaroupim (Portugal). In Proceedings of the 43rd International Symposium on Essential Oils, Lisboa, Portugal, 5-8 September 2012; p. 216.

28. Luis, A.; Duarte, A.P.; Pereira, L.; Domingues, F. Chemical profiling and evaluation of antioxidant and anti-microbial properties of selected commercial essential oils: A comparative study. Medicines 2017, 4, 36. [CrossRef] [PubMed]

29. Ciesla, L.M.; Wojtunik-Kulesza, K.A.; Oniszczuk, A.; Waksmundzka-Hajnos, M. Antioxidant synergism and antagonism between selected monoterpenes using the 2,2-diphenyl-1-picrylhydrazyl method. Flavour Fragr. J. 2016, 31, 412-419. [CrossRef]

30. Wojtunik, K.A.; Ciesla, L.M.; Waksmundzka-Hajnos, M. Model studies on the antioxidant activity of common terpenoid constituents of essential oils by means of the 2,2-diphenyl-1-picrylhydrazyl method. J. Agric. Food Chem. 2014, 62, 9088-9094. [CrossRef] [PubMed] 
31. Aazza, S.; Lyoussi, B.; Miguel, M.G. Antioxidant and antiacetylcholinesterase activities of some commercial essential oils and their major compounds. Molecules 2011, 16, 7672-7690. [CrossRef] [PubMed]

32. Li, G.-X.; Liu, Z.-Q. Unusual antioxidant behavior of $\alpha$ - and $\gamma$-terpinene in protecting methyl linoleate, DNA, and erythrocyte. J. Agric. Food Chem. 2009, 57, 3943-3948. [CrossRef] [PubMed]

33. Kim, G.-L.; Seon, S.-H.; Rhee, D.-H. Pneumonia and Streptococcus pneumoniae vaccine. Arch. Pharm. Res. 2017, 40, 885-893. [CrossRef] [PubMed]

34. Hendry, E.R.; Worthington, T.; Conway, B.R.; Lambert, P.A. Antimicrobial efficacy of eucalyptus oil and 1,8-cineole alone and in combination with chlorhexidine digluconate against microorganisms grown in planktonic and biofilm cultures. J. Antimicrob. Chemother. 2009, 64, 1219-1225. [CrossRef] [PubMed]

35. Aazza, S.; Lyoussi, B.; Megías, C.; Cortés-Giraldo, I.; Vioque, J.; Figueiredo, A.C.; Miguel, M.G. Anti-oxidant, anti-inflammatory and anti-proliferative activities of Moroccan commercial essential oils. Nat. Prod. Commun. 2014, 9, 587-594. [PubMed]

(C) 2018 by the authors. Licensee MDPI, Basel, Switzerland. This article is an open access article distributed under the terms and conditions of the Creative Commons Attribution (CC BY) license (http:/ / creativecommons.org/licenses/by/4.0/). 